\title{
Moderate sewage sludge biochar application on alkaline soil for corn growth: a field study
}

\author{
Shengyu Xie ${ }^{1,2} \cdot$ Guangwei Yu$^{1} \cdot$ Ruqing Jiang ${ }^{1} \cdot$ Jianli Ma $^{3} \cdot$ Xiaofu Shang ${ }^{3} \cdot$ Gang Wang $^{1} \cdot$ Yin Wang $^{1} \cdot$ Yongan Yang $^{4}$. \\ Chunxing $\mathrm{Li}^{5}$
}

Received: 2 October 2020 / Accepted: 12 January 2021 / Published online: 19 February 2021

(c) The Author(s) 2021

\begin{abstract}
In view of the risks induced by the inhibitory effects of applying impracticably large amounts of sewage sludge biochar (SSB) to the alkaline soil, this field study investigated the influence of moderate biochar amendments $(0,1500,4500$, and $9000 \mathrm{~kg} /$ $\mathrm{hm}^{2}$ ) on corn growth, alkaline soil properties, and the uptake of potentially toxic elements (PTEs). The results showed that applying more SSB would decrease the ammonium nitrogen concentration and increase the available phosphorus and potassium concentrations, which inhibited corn plant growth because of high background nutrient levels of the alkaline soil. When the alkaline soil was amended with $1500 \mathrm{~kg} / \mathrm{hm}^{2} \mathrm{SSB}$, the dry weight of 100 niblets increased from $32.11 \mathrm{~g}$ in the control to $35.07 \mathrm{~g}$. There was no significant variation in the total concentration of PTEs in the soil. The concentrations of $\mathrm{Mn}, \mathrm{Ni}$, $\mathrm{Cu}$, and $\mathrm{Zn}$ in niblets decreased from 5.54, 0.83, 2.26, and $27.15 \mathrm{mg} / \mathrm{kg}$ in the control to 4.47, 0.62, 1.30, and $23.45 \mathrm{mg} / \mathrm{kg}$, respectively. Accordingly, the health risk from corn consumption was significantly reduced. Furthermore, the combination of SSB and fertilizer improved corn growth and reduced the risk of consumption of PTEs. Therefore, considering the increase in corn fruit yield and the decrease in consumption risk, applying $1500 \mathrm{~kg} / \mathrm{hm}^{2}$ of biochar to alkaline soils is a realistically achievable rate, which can broaden the utilization of SSB for remediation of different types of soil.
\end{abstract}

Keywords Sewage sludge biochar $\cdot$ Alkaline soil $\cdot$ Corn growth $\cdot$ Soil property $\cdot$ Potentially toxic elements $\cdot$ Soil remediation

\section{Abbreviations \\ SSB Sewage sludge biochar \\ PTE Potentially toxic element \\ EC Electrical conductivity \\ EDI Estimated daily intake \\ HQ Hazard quotient}

Guangwei Yu

gwyu@iue.ac.cn

1 CAS Key Laboratory of Urban Pollutant Conversion, Institute of Urban Environment, Chinese Academy of Sciences, Xiamen 361021, China

2 Graduate School of Environmental Studies, Tohoku University, 6-6-07 Aoba, Aramaki-aza, Aoba-ku, Sendai, Miyagi 980-8579, Japan

3 Tianjin Academy of Environmental Sciences, Tianjin 300191, China

4 Tianjin High Quality Agricultural Products Development Demonstration Center, Tianjin 301508, China

5 Department of Environmental Engineering, Technical University of Denmark, 2800 Kongens Lyngby, Denmark

\section{Introduction}

Pyrolysis is a proven and promising technology for the harmfree treatment of sewage sludge while generating functional products such as biochar, oil, and gas. In slow pyrolysis with a low heating rate $\left(<10^{\circ} \mathrm{C} / \mathrm{min}\right)$ and long residence time ( $>1 \mathrm{~h}$ ), biochar is the main byproduct (Oni et al. 2019). Converting sewage sludge into sewage sludge biochar (SSB) has additional advantages such as volume reduction, pollutant elimination, and nutrient retention (Wu et al. 2019). Additionally, some potentially toxic elements (PTEs: Cr, $\mathrm{Mn}, \mathrm{Ni}, \mathrm{Cu}, \mathrm{Zn}, \mathrm{As}, \mathrm{Cd}$, and $\mathrm{Pb}$ ) in untreated sewage sludge can cause potential threats to humans via the food chain (Khan et al. 2020). In our previous study, we studied the migration and transformation behavior of PTEs in the sewage sludge pyrolysis process from laboratory- to pilot-scale experiments, and found that most of the PTEs remained in the SSB and were converted from bioavailable fractions to a more stable fraction combined with silicate minerals $(\mathrm{Li}$ et al. 2018a, 2021; Xie et al. 2020a). Considering the high 
concentrations of PTEs in SSB, its proper utilization still attracts much attention and requires further investigation.

Currently, the application of biochar for soil remediation is an attractive method with numerous benefits. For example, the porosity of biochar can increase the water-holding capacity and decrease the bulk density of soil, which increases vegetable productivity and reduces irrigation frequency (Liu et al. 2020). Functional groups such as $-\mathrm{COO}^{-}$and $\mathrm{O}^{-}$in the surface of biochar can react with $\mathrm{H}^{+}$in soil to improve the buffering capacity of soil (Wu et al. 2020b). Additionally, the chemical properties and enzymatic activities of the soil are significantly improved after biochar amendment (Pokharel et al. 2020; Rafael et al. 2019). Biochar can also reduce the bioavailability and toxicity of soil by adsorbing and degrading organic contaminants (Wu et al. 2020a).

SSB differs from other types of biochar, and further investigation is needed on the safety of SSB with high PTE concentrations applied to large-scale plantings (Purakayastha et al. 2019). It has been reported that excess PTEs have a negative effect on vegetative growth. More specifically, excess $\mathrm{Zn}$ can cause chlorosis in plant leaves, excess $\mathrm{Cu}$ may cause negative effects on plant nutrients, and large amounts of $\mathrm{Ni}$ and $\mathrm{Co}$ can reduce seed germination and inhibit the growth of plant tissues (Khan et al. 2020; Mohamed et al. 2017). Therefore, several studies have been conducted to investigate the accumulation of PTEs in plant tissues after addition of biochar to soil. The results showed that biochar significantly decreased the concentrations of mobile fractions (water-soluble, exchangeable, and bound-to-carbonate fractions) of $\mathrm{Ni}, \mathrm{Zn}, \mathrm{Cd}$, and $\mathrm{Pb}$ in soil, and reduced their concentrations in oilseed rape tissues (Shaheen and Rinklebe 2015; Shaheen et al. 2015). Khan et al. (2013) found that 5-10 wt\% SSB amendment decreased the uptake of some PTEs (As, $\mathrm{Cr}, \mathrm{Co}, \mathrm{Ni}$, and $\mathrm{Pb}$ ) in rice tissues as a result of increasing the $\mathrm{pH}$, cation exchange capacity, pore structure, and dissolved organic carbon concentration of acidic soil. In addition, the reduction in PTE bioaccumulation of SSB has been verified in other plants such as grass, Chinese cabbage, and tomato (Hossain et al. 2010; Yu et al. 2018; Yue et al. 2017). In our previous study, we found that $5-10 \mathrm{wt} \%$ SSB is the suitable proportion to use in soilless cultivation, and only small amounts of the PTEs in biochar were taken up by cucumber plants (Xie et al. 2020b). Nonetheless, the health risk associated with food consumption from applying SSB to agriculture needs further verification based on a field study.

Most studies have focused on the effect of biochar addition on acidic and infertile soils (Mohamed et al. 2017; Wu et al. 2020b). The observed benefits are that the addition of alkaline biochar can significantly increase soil $\mathrm{pH}$, which influences the microbial response and PTE solubility (Zhu et al. 2017). In northern China, where corn is the main crop, most soils are alkaline, containing $\mathrm{NaCO}_{3}$ and $\mathrm{NaHCO}_{3}$. Low water retention and organic matter levels also restrict the development of local agricultural production (Liu et al. 2020), and SSB may have a positive effect in alkaline soils because of its pore structure, functional groups, and nutrients. However, based on a field soil study considering the volume and cost of biochar, 5-10 wt\% SSB $(\sim 100,000 \mathrm{~kg} /$ $\mathrm{hm}^{2}$ ) is not practicable (Kocsis et al. 2020; Zhang et al. 2016). Additionally, excessive application of SSB adversely affects plant growth and PTE availability if the soil $\mathrm{pH}$ is greater than 8.0 (Artiola et al. 2012). Therefore, the application of moderate levels of SSB $\left(<10,000 \mathrm{~kg} / \mathrm{hm}^{2}\right)$ to alkaline soil is worthy of further attention for broadening the utilization of SSB on different types of soil.

In view of the few reports in this regard, a field trial was conducted to study the effect of moderate SSB addition on the alkaline soil for corn planting. We analyzed the influence of SSB on soil properties, including water retention, $\mathrm{pH}$, electrical conductivity (EC), and nutrient content during corn growth. Furthermore, the concentrations and chemical speciation of PTEs in soil were also studied to investigate their accumulation in corn fruits and the potential health risks posed to humans. Our primary objective was to verify, in a field study, whether moderate applications of SSB are suitable for alkaline soils.

\section{Materials and methods}

\subsection{Biochar and planting location}

SSB was prepared by pyrolysis of hydrothermally treated sewage sludge at $600{ }^{\circ} \mathrm{C}$ for $45 \mathrm{~min}$ in a sewage sludge treatment plant in Xiamen City, Fujian Province, China, to reduce the pollutant risk ( $\mathrm{Li}$ et al. 2018a; Tian et al. 2019). The obtained biochar was ground and passed through a $3.2 \mathrm{~mm}$ sieve prior to use in the field trial. The planting experiment was conducted at a national corn farm in Tianjin, China $\left(39^{\circ} 25.459 \mathrm{~N}, 117^{\circ} 29.295 \mathrm{E}\right)$, where the annual average temperature is $12-15{ }^{\circ} \mathrm{C}$ and the total annual precipitation is $550-600 \mathrm{~mm}$, with a temperate continental monsoon climate. The basic properties of the soil and SSB are described in Table 1.

\subsection{Field trial}

Four different treatments with SSB amendments (0 [CK], 1500 [C1], 4500 [C3], and $9000 \mathrm{~kg} / \mathrm{hm}^{2}$ [C4]) were used to investigate the influence of SSB addition on alkaline soil properties and corn growth under normal fertilization conditions. Additionally, to study the influence of fertilization, treatment with $1500 \mathrm{~kg} / \mathrm{hm}^{2} \mathrm{SSB}$ application without fertilization $(\mathrm{C} 2)$ was established. The total length and width of the trial site were $65 \mathrm{~m}$ and $26 \mathrm{~m}$, respectively. The area of each treatment was approximately $333 \mathrm{~m}^{2}$, which was 
Table 1 Basic properties of the soil and sewage sludge biochar

\begin{tabular}{lrrllr}
\hline Items & Soil & SSB & Items $(\mathrm{mg} / \mathrm{kg})$ & Soil & \multicolumn{1}{c}{ SSB } \\
\hline $\mathrm{pH}$ & 7.65 & 8.13 & $\mathrm{Cr}$ & 62.62 & 9623.30 \\
$\mathrm{EC}(\mathrm{mS} / \mathrm{cm})$ & 2.06 & 2.68 & $\mathrm{Mn}$ & 433.83 & 958.65 \\
$\mathrm{C}(\%)$ & 1.27 & 7.81 & $\mathrm{Ni}$ & 22.77 & 1409.99 \\
$\mathrm{H}(\%)$ & 1.19 & 1.32 & $\mathrm{Cu}$ & 14.82 & 8608.33 \\
$\mathrm{~N}(\%)$ & 0.38 & 0.35 & $\mathrm{Zn}$ & 79.37 & 8293.10 \\
$\mathrm{~S}(\%)$ & 0.09 & 1.71 & $\mathrm{As}$ & 44.88 & 39.97 \\
$\mathrm{~K}(\mathrm{~g} / \mathrm{kg})$ & 23.02 & 9.93 & $\mathrm{Cd}$ & $-^{\mathrm{a}}$ & 2.32 \\
$\mathrm{P}(\mathrm{g} / \mathrm{kg})$ & 1.56 & 47.62 & $\mathrm{~Pb}$ & 21.52 & 130.23 \\
\hline
\end{tabular}

${ }^{\text {a Not detected }}$

divided into three zones, as shown in Fig. 1. Before sowing corn seeds (Jingnongke 728), SSB was added to the soil surface, and an agricultural rotary tiller was used to mix the surface soil and SSB fully (15 cm in depth). The row spacing for corn sowing was $60 \mathrm{~cm}$. The corn growth period was divided into the initial stage (before seeding), budding stage, jointing stage, filling stage, and maturity stage. Water management was conducted according to the practical operation of the local farm. At the initial stage, $600 \mathrm{~kg} / \mathrm{hm}^{2}$ of base fertilizer $\left(\mathrm{N}-\mathrm{P}_{2} \mathrm{O}_{5}-\mathrm{K}_{2} \mathrm{O} \geq 46 \%\right)$ was added to the top $10-15 \mathrm{~cm}$ of soil. Additionally, $450 \mathrm{~kg} /$ $\mathrm{hm}^{2}$ of urea $(\mathrm{N} \geq 46 \%)$ was added after the jointing stage. At each growth stage, approximately $1 \mathrm{~kg}$ of soil sample was collected by the quartering method in each zone. Corn fruits, including niblets and corncobs, were collected separately after harvest. All samples were transferred to the laboratory for further analysis. Photographs of the field plantings are shown in Fig. 1.
Fig. 1 Schematic diagram and photographs of the field plantings

\section{Schematic diagram of trial site}

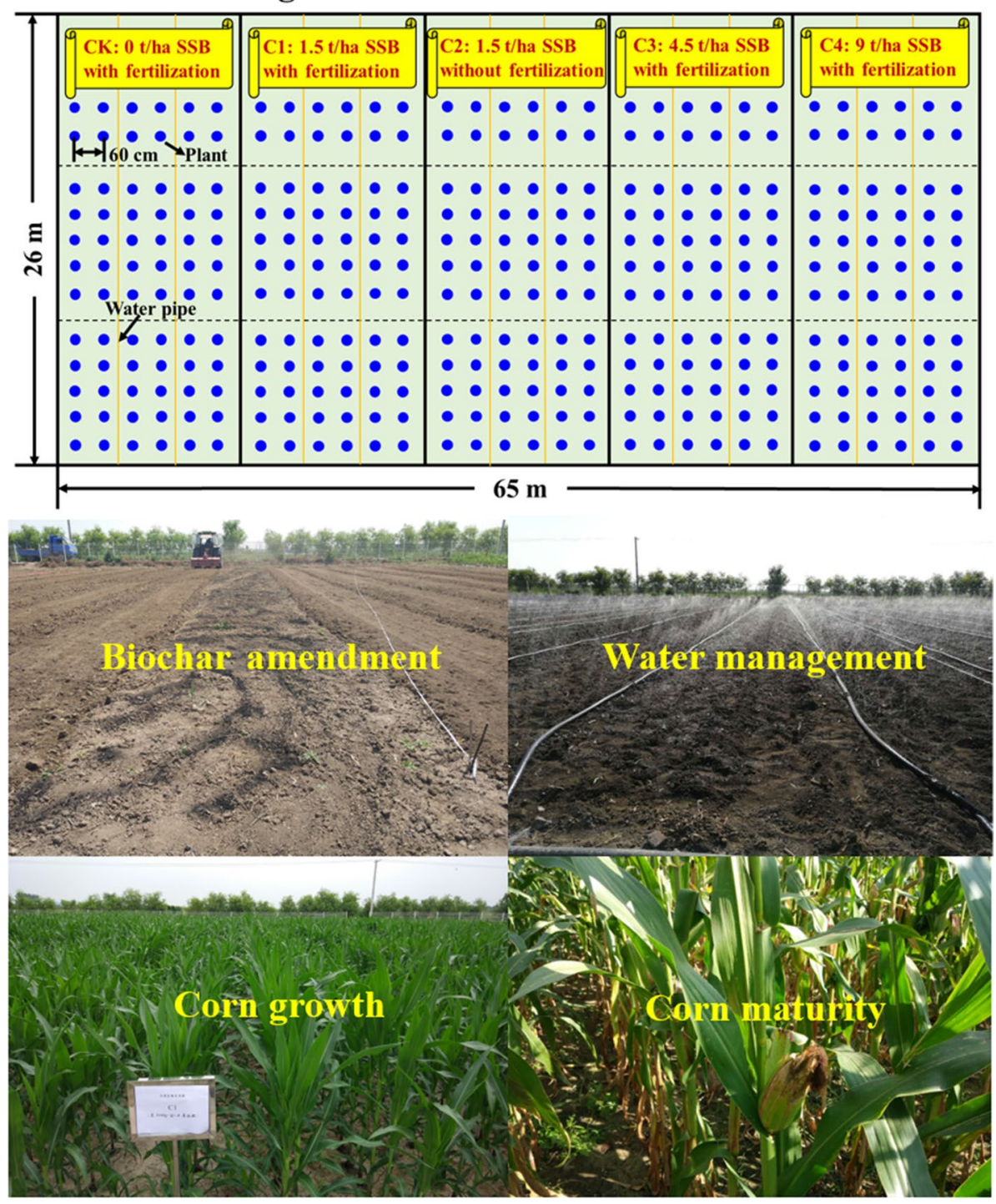




\subsection{Analysis methods}

After corn maturity, nine plants were randomly selected from each treatment. The height of each plant was measured from the soil surface to the uppermost growing point. The leaf area was calculated from the maximum length and width. The stem diameter was measured at a location $1 \mathrm{~cm}$ below the largest leaf. Further details have been described in our previous study (Xie et al. 2020b). The dry weight of 100 niblets was measured and used as an important growth parameter. The obtained soil and corn fruits were dried until their weight could be determined, then ground, sieved $(<0.15 \mathrm{~mm})$, and stored in a vacuum desiccator. The moisture content of the soil was determined by the mass difference before and after drying at $105{ }^{\circ} \mathrm{C}$ for $12 \mathrm{~h}$ according to the Chinese standard (NY/T 52-1987). The $\mathrm{pH}$ and EC of the soil were measured with a $\mathrm{pH}$ meter (Ultra Basic, US) and a conductometer (Teltracon 325, Germany), respectively, according to the Chinese standards (NY/T 1377-2007 and HJ 802-2016). The concentrations of nutrient elements (ammonium nitrogen, available phosphorus, and available potassium) were measured by a colorimetric method using a high-precision soil fertilizer nutrient meter (HMQ800, China). The total concentrations of PTEs $(\mathrm{Cr}, \mathrm{Mn}, \mathrm{Ni}, \mathrm{Cu}$, $\mathrm{Zn}, \mathrm{As}, \mathrm{Cd}$, and $\mathrm{Pb}$ ) were digested using a mixture of nitric acid, perchloric acid, and hydrofluoric acid (5:5:2, v/v/v) in a graphite digester at $190{ }^{\circ} \mathrm{C}$. The chemical speciation (F1: exchangeable, F2: reducible, F3: oxidizable, and F4: residual fractions) was determined by a three-step extraction procedure. The samples $(0.5 \mathrm{~g})$ were extracted in turn using $20 \mathrm{~mL}$ of acetic acid $(0.11 \mathrm{~mol} / \mathrm{L}), 20 \mathrm{~mL}$ of hydroxylamine hydrochloride $(0.5 \mathrm{~mol} / \mathrm{L}), 10 \mathrm{~mL}$ of hydrogen peroxide (30\%) digestion, and $25 \mathrm{~mL}$ of ammonium acetate ( $1 \mathrm{~mol} / \mathrm{L})$. Detailed information has been reported in the previous study (Xie et al. 2019, 2020b). Specifically, F1 is the fraction from acid-soluble or carbonate-combined metals, F2 is the fraction combined with iron and manganese oxides, F3 is the fraction associated with sulfur or organic matter, and F4 is the fraction bound to silicate minerals. All solutions were tested with inductively coupled plasma mass spectrometry (ICP-MS, Agilent 7500cx, USA) after filtration.

\subsection{Health risk assessment}

The estimated daily intake (EDI) and hazard quotient (HQ) indices of PTEs, which have been widely used in the health risk assessment of cilantro, spinach, and rice plantings (Khan et al. 2014,2020; Zhang et al. 2016), were calculated using the following equations:

$\mathrm{EDI}=\left(\mathrm{Con}_{\mathrm{PTE}} \times \mathrm{IR}_{\text {niblet }}\right) / \mathrm{BW}$, where $\mathrm{Con}_{\mathrm{PTE}}$, $\mathrm{IR}_{\text {niblet }}$, and BW represent the PTE concentration in niblets $(\mathrm{mg} / \mathrm{kg})$, the corn intake rate $[398.2 \mathrm{~g} / \mathrm{adult} /$ day (Zheng et al. 2007)], and average body weight [56.8 kg (Khan et al. 2014)], respectively.

$\mathrm{HQ}=\mathrm{EDI} / \mathrm{R}_{\mathrm{f}} \mathrm{D}$,

where $\mathrm{R}_{\mathrm{f}} \mathrm{D}$ represents the oral reference dose, and the values of $\mathrm{Cr}, \mathrm{Mn}, \mathrm{Ni}, \mathrm{Cu}, \mathrm{Zn}, \mathrm{As}, \mathrm{Cd}$, and $\mathrm{Pb}$ are 1500, 140, 20, $40,300,0.3,3$, and $3.5 \mu \mathrm{g} / \mathrm{kg} /$ day, respectively (Khan et al. 2020; Shehata and Galal 2020).

\subsection{Statistical analysis}

All statistical tests were performed using the Statistical Package for the Social Sciences (SPSS) Version 20.0. One-way analysis of variance (ANOVA) and Tukey's honest significant difference test were used to determine the differences in treatments. Data from different treatments showed significant differences when $P$ was less than 0.05 . Pearson correlation was used to show the relationships between soil properties and the chemical speciation of PTEs.

\section{Results and discussion}

\subsection{Effects of SSB amendments on corn growth}

The effects of SSB additions on different growth parameters after maturity are shown in Fig. 2. An increased amount of SSB amendment $\left(\geq 4500 \mathrm{~kg} / \mathrm{hm}^{2}\right)$ significantly decreased the plant height, leaf area, and stem diameter of corn plants (Fig. 2a-c). Additionally, treatment without fertilization (C2) markedly inhibited the growth of corn leaves. A small leaf area indicates weakening of chlorophyll synthesis and photosynthesis during growth ( $\mathrm{Li}$ et al. 2018b). However, the variation in dry weight of 100 niblets after SSB application was not affected by inferior plant height, leaf area, and stem diameter, as shown in Fig. 2d. The dry weight of 100 niblets of corn plants increased by $9.2 \%, 6.4 \%$, and $7.1 \%$, respectively, with the addition of 1500,4500 , and $9000 \mathrm{~kg} /$ $\mathrm{hm}^{2}$ of SSB (C1, C3, and C4 treatment) compared with CK. Moreover, the absence of fertilizer $(\mathrm{C} 2)$ caused a reduction in the dry weight of 100 niblets compared with the $\mathrm{C} 1$ treatment (decreased from 35.07 to $32.56 \mathrm{~g}$ ). The impact of SSB on corn growth was determined by soil properties, which will be discussed in the next section. In general, the addition of SSB could increase the yield of corn fruits, although it inhibited plant growth, and the combination of SSB and fertilizer could yield better results. The SSB rate of $1500 \mathrm{~kg} /$ $\mathrm{hm}^{2}$ was optimal as an alkaline soil amendment for corn 

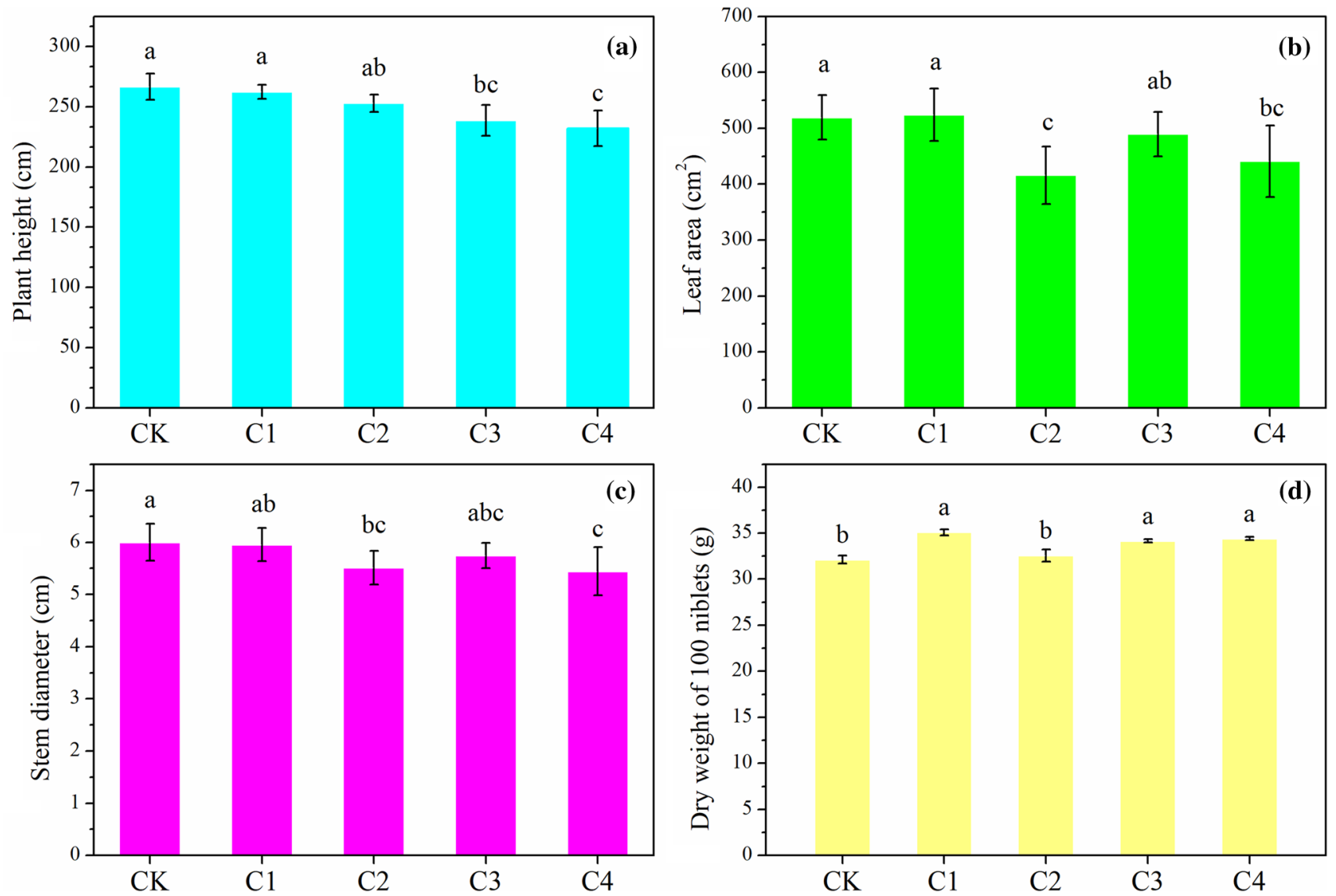

Fig. 2 Growth performance of corn plants after maturity in different treatments. Letters indicate significant differences among treatments $(P<0.05)$

growth, ensuring the highest fruit yield. Zhang et al. (2016) also reported that modest applications of SSB $(<5000 \mathrm{~kg} /$ $\mathrm{hm}^{2}$ ) increased rice grain yields in a field study.

\subsection{Effects of SSB amendments on physicochemical properties of soil}

\subsubsection{Soil moisture, $\mathrm{pH}$, and EC}

The basic properties of the alkaline soil, including moisture, $\mathrm{pH}$, and $\mathrm{EC}$, were investigated at different growth stages. Before seeding, there was an insignificant difference among the five trial areas with $14-18 \%$ of soil moisture (Fig. 3a).
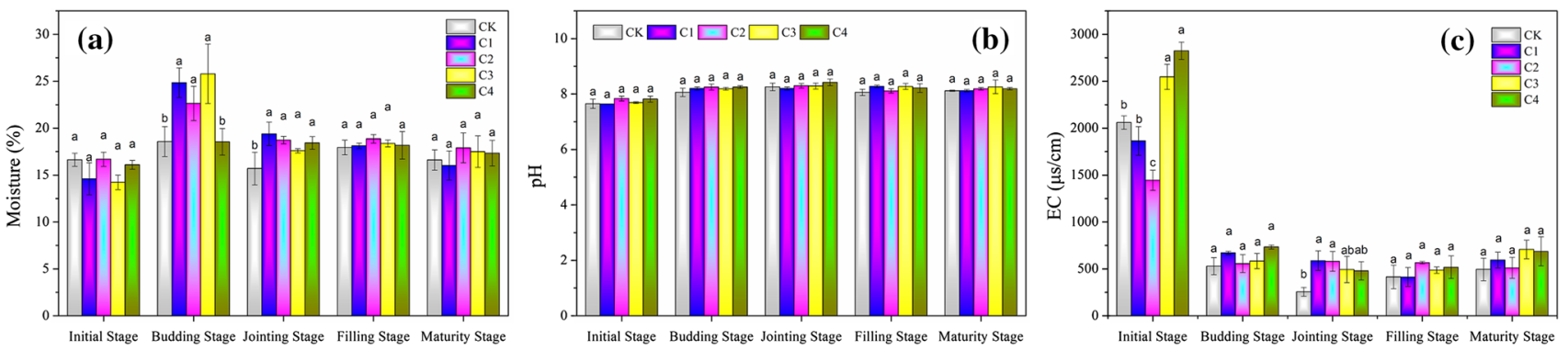

Fig. 3 Variation in a soil moisture, $\mathbf{b} \mathrm{pH}$ and $\mathbf{c}$ electrical conductivity during growth. Letters indicate significant differences among treatments $(P<0.05)$ 
The increase in moisture during the budding stage can be attributed to artificial water management based on local experience. Furthermore, moderate SSB amendments increased soil moisture at the budding and jointing stages compared with $\mathrm{CK}$, indicating that, owing to its porous structure, SSB can improve the water-holding capacity of soil when corn needs water to grow, similar to the findings of Haider et al. (2017). There was no significant change in soil moisture at other stages because the water-holding capacity of SSB is not sustainable and will change with soil environmental variation ( $\mathrm{Li}$ et al. 2020). Moreover, the $\mathrm{pH}$ range of soil for the five treatments was 7.6-7.9 (Fig. 3b). The soil $\mathrm{pH}$ was in dynamic equilibrium and showed insignificant variation during corn growth. This is because soil $\mathrm{pH}$ is controlled by the leaching of basic cations $(\mathrm{Ca}, \mathrm{Mg}$, $\mathrm{K}$, and $\mathrm{Na}$ ), the release of $\mathrm{H}^{+}$from carbonic acid produced by $\mathrm{CO}_{2}$ dissolution, organic matter humification, and the input and output of N (Liu et al. 2020; Neina 2019). However, a small amount of SSB application could not markedly increase the $\mathrm{pH}$ of the alkaline soil because of its high background level, indicating that the current SSB amount is reasonable because higher soil $\mathrm{pH}$ may have adverse effects on plant growth and PTE availability (Artiola et al. 2012). For soil EC (Fig. 3c), there were significant differences among the five treatments $(1400-2600 \mu \mathrm{s} / \mathrm{cm})$ and a greater amount of SSB $\left(\geq 4500 \mathrm{~kg} / \mathrm{hm}^{2}\right)$ significantly increased the soil EC. Specifically, the C1 and C2 treatments were rated as non-saline soil $(0-2000 \mu \mathrm{s} / \mathrm{cm})$ and other treatments were classified as slightly saline soil (2000-4000 $\mu \mathrm{s} /$ $\mathrm{cm}$ ) (Scianna 2002). The EC in all treatments presented a trend of first decrease and then stabilization during growing stages because the accumulated nutrients and minerals in the soil would have been adsorbed and utilized by corn plants (Negasa et al. 2017). In addition, the differences in EC for the five trial areas reduced after corn planting, which suggests that plant cultivation can modify the EC level of soil. Additionally, there was no significant difference in soil EC in the other stages, although the EC level of the $\mathrm{C} 2$ treatment was lower than that of CK in the initial stage. This is because SSB gradually releases the available nutrients $\left(\mathrm{K}^{+}\right.$,
$\mathrm{Ca}^{2+}, \mathrm{Mg}^{2+}$, and $\mathrm{PO}_{4}{ }^{3-}$ ) and increases the amount of total dissolved salts (Figueiredo et al. 2018; Yue et al. 2017). SSB should be applied to alkaline soils at controlled proportions to avoid potential toxicity to corn plants.

\subsubsection{Soil nutrient elements}

Ammonium nitrogen is an important nutrient component in soil and can be easily absorbed by plants because of its high solubility. However, acidic ammonium ions will be neutralized in alkaline soils and lead to nitrogen volatilization (Mandal et al. 2016). As shown in Fig. 4a, the concentration of ammonium nitrogen first increased and then decreased as growth progressed. The increase in ammonium nitrogen in the filling stage was attributed to the second fertilizer application. In the budding stage, the ammonium nitrogen concentrations in other treatments with SSB application were lower than $91.25 \mathrm{mg} / \mathrm{kg}$ in $\mathrm{CK}$, and their concentrations were lower for $\mathrm{C} 3$ and $\mathrm{C} 4$ treatments. A similar phenomenon also occurred at the maturity stage. These results indicate that an increase in SSB application to alkaline soils will decrease the concentration of ammonium nitrogen in the soil and promote volatilization of ammonia. The loss of nitrogen may have a negative impact on corn growth. Sun et al. (2019) also observed that $\mathrm{NH}_{3}$ volatilization and $\mathrm{N}_{2} \mathrm{O}$ emissions increased in acidic soils after the addition of more wheat straw alkaline biochar $\left(20,000 \mathrm{~kg} / \mathrm{hm}^{2}\right)$. Phosphorus and potassium, as essential elements, have been shown to enhance fruit growth (Hossain et al. 2011; Zeeshan et al. 2020). The variation in available phosphorus and potassium concentrations showed a similar trend during growth (Fig. 4b, c). In particular, their concentrations in the soil were markedly elevated after the addition of increased SSB amendments (C3 and C4 treatments) in the budding stage. Therefore, SSB application had a positive influence on soil fertility by increasing the concentrations of available phosphorus and potassium. Furthermore, SSB had no effect on available nutrient concentration in the soil at the filling and maturity stages because the immobilization of available nutrient mitigated this increasing trend. However, the corn
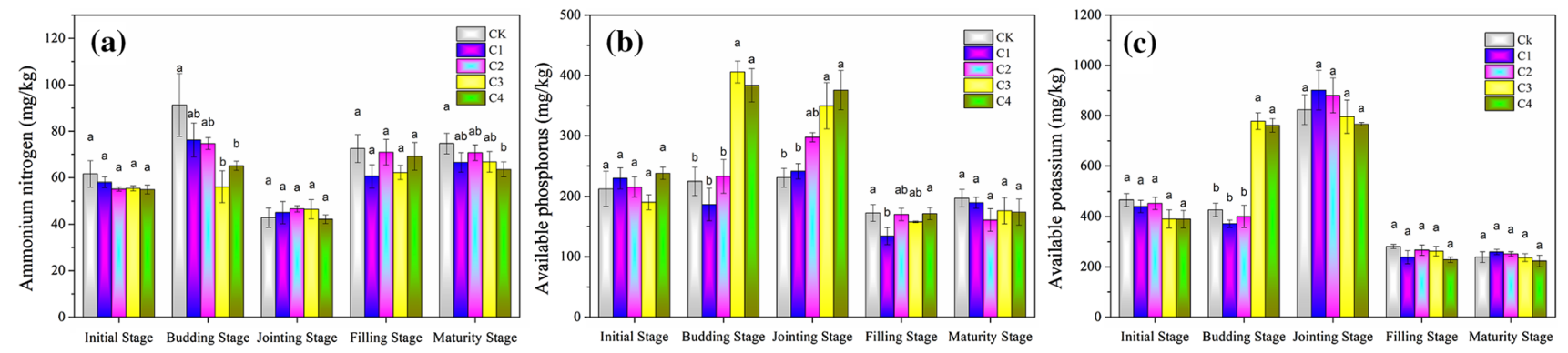

Fig. 4 Variation in a ammonium nitrogen, $\mathbf{b}$ available phosphorus, and $\mathbf{c}$ available potassium concentrations in the soil during growth. Letters indicate significant differences among treatments $(P<0.05)$ 
plants in the $\mathrm{C} 3$ and $\mathrm{C} 4$ treatments had a weaker growth status than those in CK. These results can be attributed to the fact that the alkaline soil used in the present study, with high background nutrient levels, can reduce nutrient uptake and inhibit plant growth after higher amounts of SSB are added (Ding et al. 2016; Zhang et al. 2010). Corn fruit accumulates more nutrients than other tissues, which is why corn yield has not been affected (El-Fouly et al. 2012). However, the detailed reason needs to be further investigated.

\subsection{Effects of SSB amendments on PTE in soil}

\subsubsection{Total PTE concentrations}

Although SSB has high PTE concentrations, as listed in Table 1, moderate SSB amendments had no significant effects on total PTE concentrations in the soil in the initial stage (Table 2), whose values were lower than the risk screening values based on the Chinese standard (GB 15618-2018, Cr: $250 \mathrm{mg} / \mathrm{kg}$; Ni: $190 \mathrm{mg} / \mathrm{kg}$; Cu: $100 \mathrm{mg} /$ $\mathrm{kg}$; Zn: $300 \mathrm{mg} / \mathrm{kg}$; $\mathrm{Cd}: 0.6 \mathrm{mg} / \mathrm{kg}$; and $\mathrm{Pb}: 170 \mathrm{mg} / \mathrm{kg}$ ), indicating a lower risk. The concentration did not exceed the risk intervention value $(100 \mathrm{mg} / \mathrm{kg})$ for soil contamination of agricultural land, although it was higher than the risk screening value $(25 \mathrm{mg} / \mathrm{kg})$. The Cd concentration in the soil could not be detected in the initial stage owing to its extra low level. Yue et al. (2017) verified that the concentrations of $\mathrm{Zn}, \mathrm{Cu}, \mathrm{Cr}, \mathrm{Pb}, \mathrm{As}$, and $\mathrm{Cd}$ the potting soil significantly increased in response to increasing amounts (1-50 wt\%) of applied SSB. Therefore, the proportion of SSB applied should be considered, and a moderate proportion would bring low environmental risk for soil in terms of total PTE concentrations. During the growth process, the soil concentrations of $\mathrm{Cr}, \mathrm{Ni}, \mathrm{Cu}, \mathrm{Zn}$, and As showed decreased trends, indicating that these PTEs migrated from soil into corn plants. Moreover, the concentrations of $\mathrm{Mn}, \mathrm{Cd}$, and $\mathrm{Pb}$ varied irregularly due to the synergy between organic matter decomposition and plant uptake (Li et al. 2017; Xie et al. 2020b). Minor differences were also observed between CK and other treatments with the addition of SSB at the maturity stage. Furthermore, the concentrations of $\mathrm{As}$ and $\mathrm{Pb}$ at the maturity stage and the $\mathrm{Cd}$ concentrations at the jointing, filling, and maturity stages in the $\mathrm{C} 2$ treatment were higher than those in the $\mathrm{C} 1$ treatment, indicating that the absence
Table 2 Potentially toxic element concentrations in the alkaline soil during growth

\begin{tabular}{|c|c|c|c|c|c|c|c|c|c|}
\hline Stage & Treatment & $\mathrm{Cr}$ & $\mathrm{Mn}$ & $\mathrm{Ni}$ & $\mathrm{Cu}$ & $\mathrm{Zn}$ & As & $\mathrm{Cd}$ & $\mathrm{Pb}$ \\
\hline \multirow[t]{5}{*}{ Initial } & $\mathrm{CK}$ & $62.62 \mathrm{a}^{\mathrm{a}}$ & $433.83 a$ & $22.77 \mathrm{a}$ & $14.82 \mathrm{a}$ & $79.37 \mathrm{a}$ & $44.88 \mathrm{a}$ & $-^{\mathrm{b}}$ & $21.52 \mathrm{a}$ \\
\hline & $\mathrm{C} 1$ & $59.68 \mathrm{a}$ & $410.58 \mathrm{a}$ & $21.77 \mathrm{ab}$ & $14.02 \mathrm{ab}$ & $77.43 \mathrm{a}$ & $42.63 a$ & - & $20.21 \mathrm{ab}$ \\
\hline & $\mathrm{C} 2$ & $61.33 \mathrm{a}$ & $418.15 a$ & $22.16 \mathrm{a}$ & $12.78 \mathrm{~b}$ & $77.98 \mathrm{a}$ & $44.52 \mathrm{a}$ & - & $18.52 \mathrm{ab}$ \\
\hline & $\mathrm{C} 3$ & $55.15 \mathrm{a}$ & $361.43 b$ & $19.52 \mathrm{~b}$ & $12.65 \mathrm{~b}$ & $69.38 b$ & $41.34 \mathrm{a}$ & - & $18.05 b$ \\
\hline & $\mathrm{C} 4$ & $59.23 \mathrm{a}$ & $417.55 \mathrm{a}$ & $20.86 a b$ & $14.99 \mathrm{a}$ & $78.72 \mathrm{a}$ & $42.30 \mathrm{a}$ & - & $19.07 \mathrm{ab}$ \\
\hline \multirow[t]{5}{*}{ Budding } & $\mathrm{CK}$ & $47.60 \mathrm{a}$ & $330.57 \mathrm{a}$ & $16.83 a$ & $13.21 \mathrm{a}$ & $49.96 \mathrm{a}$ & $22.8 \mathrm{a}$ & $0.20 \mathrm{a}$ & $26.23 \mathrm{a}$ \\
\hline & $\mathrm{C} 1$ & $45.88 \mathrm{a}$ & $333.43 \mathrm{a}$ & $16.64 \mathrm{a}$ & $13.08 \mathrm{a}$ & $48.15 \mathrm{a}$ & $21.21 \mathrm{ab}$ & $0.21 \mathrm{a}$ & $27.09 \mathrm{a}$ \\
\hline & $\mathrm{C} 2$ & $47.04 \mathrm{a}$ & $311.5 \mathrm{ab}$ & $15.87 \mathrm{ab}$ & $13.53 \mathrm{a}$ & $46.17 \mathrm{a}$ & $19.35 \mathrm{bc}$ & $0.17 b$ & $24.82 \mathrm{ab}$ \\
\hline & $\mathrm{C} 3$ & $46.07 \mathrm{a}$ & $312.2 \mathrm{ab}$ & $16.05 \mathrm{ab}$ & $12.55 \mathrm{a}$ & $49.76 a$ & $20.93 \mathrm{ab}$ & $0.2 \mathrm{a}$ & $25.85 \mathrm{a}$ \\
\hline & $\mathrm{C} 4$ & $43.06 \mathrm{a}$ & $295.03 b$ & $14.61 \mathrm{~b}$ & $12.67 \mathrm{a}$ & $49.85 a$ & $18.23 \mathrm{c}$ & $0.17 b$ & $21.84 \mathrm{~b}$ \\
\hline \multirow[t]{5}{*}{ Jointing } & $\mathrm{CK}$ & $43.46 \mathrm{a}$ & $343.17 \mathrm{ab}$ & $15.92 \mathrm{a}$ & $12.06 \mathrm{a}$ & $41.00 \mathrm{a}$ & $19.53 b$ & $0.19 \mathrm{~b}$ & $25.36 \mathrm{a}$ \\
\hline & $\mathrm{C} 1$ & $43.55 \mathrm{a}$ & $357.13 \mathrm{ab}$ & $15.72 \mathrm{a}$ & $12.18 \mathrm{a}$ & $38.41 \mathrm{a}$ & $20.16 \mathrm{ab}$ & $0.20 \mathrm{~b}$ & $25.80 \mathrm{a}$ \\
\hline & $\mathrm{C} 2$ & $43.50 \mathrm{a}$ & $376.47 \mathrm{a}$ & $16.11 \mathrm{a}$ & $12.62 \mathrm{a}$ & $40.88 \mathrm{a}$ & $22.06 \mathrm{a}$ & $0.23 \mathrm{a}$ & $28.47 \mathrm{a}$ \\
\hline & $\mathrm{C} 3$ & $45.17 \mathrm{a}$ & $334.30 \mathrm{~b}$ & $16.45 \mathrm{a}$ & $12.41 \mathrm{a}$ & $42.10 \mathrm{a}$ & $21.44 \mathrm{ab}$ & $0.20 \mathrm{ab}$ & $27.82 \mathrm{a}$ \\
\hline & $\mathrm{C} 4$ & $43.06 \mathrm{a}$ & $336.28 b$ & $15.46 \mathrm{a}$ & $12.56 \mathrm{a}$ & $39.18 \mathrm{a}$ & $20.41 \mathrm{ab}$ & $0.20 \mathrm{ab}$ & $24.45 \mathrm{a}$ \\
\hline \multirow[t]{5}{*}{ Filling } & CK & $38.37 \mathrm{a}$ & $310.88 \mathrm{c}$ & $15.41 \mathrm{a}$ & $10.56 \mathrm{~b}$ & $38.36 \mathrm{a}$ & $16.38 \mathrm{~b}$ & $0.17 \mathrm{~b}$ & $24.30 \mathrm{ab}$ \\
\hline & $\mathrm{C} 1$ & $41.15 \mathrm{a}$ & $392.67 \mathrm{a}$ & $12.92 \mathrm{a}$ & $10.99 \mathrm{ab}$ & $39.42 \mathrm{a}$ & $20.64 a$ & $0.18 \mathrm{~b}$ & $24.28 \mathrm{ab}$ \\
\hline & $\mathrm{C} 2$ & $41.91 \mathrm{a}$ & $332.87 b$ & $13.93 \mathrm{a}$ & $10.86 \mathrm{ab}$ & $39.39 \mathrm{a}$ & $20.75 a$ & $0.20 \mathrm{a}$ & $25.24 \mathrm{a}$ \\
\hline & $\mathrm{C} 3$ & $41.18 \mathrm{a}$ & $284.15 d$ & $13.26 \mathrm{a}$ & 11.18ab & $44.01 \mathrm{a}$ & $18.09 \mathrm{~b}$ & $0.14 \mathrm{c}$ & $20.88 \mathrm{c}$ \\
\hline & $\mathrm{C} 4$ & $40.43 a$ & $304.2 \mathrm{c}$ & $11.89 \mathrm{~b}$ & $12.12 \mathrm{a}$ & $43.97 \mathrm{a}$ & $16.97 \mathrm{~b}$ & $0.16 b c$ & $21.56 \mathrm{bc}$ \\
\hline \multirow[t]{5}{*}{ Maturity } & CK & $35.56 a$ & 291.63ab & $12.78 \mathrm{a}$ & $9.66 b$ & $38.75 \mathrm{ab}$ & $16.45 \mathrm{abc}$ & $0.15 \mathrm{~cd}$ & $18.93 b$ \\
\hline & $\mathrm{C} 1$ & $34.09 \mathrm{a}$ & $270.35 b$ & $12.92 \mathrm{a}$ & $9.76 b$ & $37.10 \mathrm{~b}$ & $16.08 \mathrm{bc}$ & $0.17 b$ & $18.01 b$ \\
\hline & $\mathrm{C} 2$ & $39.13 \mathrm{a}$ & $331.30 \mathrm{a}$ & $13.93 \mathrm{a}$ & $10.74 \mathrm{ab}$ & $35.25 \mathrm{~b}$ & $19.46 \mathrm{a}$ & $0.23 \mathrm{a}$ & $22.84 \mathrm{a}$ \\
\hline & $\mathrm{C} 3$ & $39.20 \mathrm{a}$ & $288.18 b$ & $13.26 \mathrm{a}$ & $12.20 \mathrm{a}$ & $42.71 \mathrm{a}$ & $17.31 \mathrm{ab}$ & $0.16 b c$ & $19.34 b$ \\
\hline & $\mathrm{C} 4$ & $34.36 \mathrm{a}$ & $283.45 b$ & $11.89 \mathrm{a}$ & $11.32 \mathrm{ab}$ & 39.69ab & $13.94 \mathrm{c}$ & $0.13 d$ & $17.54 b$ \\
\hline
\end{tabular}

${ }^{a}$ Letters after the numerical value show significance differences with each column of data $(P<0.05)$

${ }^{\mathrm{b}}$ Not detected 
of fertilizer poses a greater risk to plant uptake of PTEs. Unlike the application of fertilizer that would induce large amounts of $\mathrm{Cd}, \mathrm{Pb}$, and As into soil, as reported by Atafar et al. (2008), this variation in PTE concentrations may be influenced by water runoff and organic matter decomposition. However, the total PTE concentrations in soil are not the only factors affecting plant uptake. The chemical speciation and distribution also affect the PTE concentrations in crop fruits (Khan et al. 2013; Yue et al. 2017).

\subsubsection{Chemical speciation of PTE}

Based on the extraction of chemical species of PTEs, F1 and F2 fractions are identified as bioavailable fractions that can be easily adsorbed by plants, and the F4 fraction stably exists in soil (Fuentes et al. 2008). With corn growth, the percentage of the F1 and F2 fractions of Mn and Zn significantly increased in the soil for the five treatments, and the percentage of the $\mathrm{F} 4$ fractions of $\mathrm{Mn}, \mathrm{Ni}, \mathrm{Cu}, \mathrm{Zn}$, and $\mathrm{As}$ decreased markedly (Fig. 5). These results indicate that corn growth has negative effects on the immobilization of PTEs, which was also observed in the soilless cultivation of plants (Xie et al. 2020b). Throughout the growth stages, there were minor variations and the $\mathrm{F} 4$ fraction was the main chemical speciation of $\mathrm{Cr}$ and $\mathrm{Pb}$ in the soil, suggesting that these PTEs stably exist in soil and are adsorbed with difficulty by corn plants.

SSB amendment had different effects on the chemical fractions of other PTEs. Specifically, compared with CK, $1500 \mathrm{~kg} / \mathrm{hm}^{2}$ of SSB amendment significantly increased the percentage of the $\mathrm{F} 4$ fraction of $\mathrm{Ni}$ in the budding stage, the percentage of the $\mathrm{F} 4$ fraction of $\mathrm{Cu}$ in the budding, jointing, filling, and maturity stages, the percentage of the F4 fraction of $\mathrm{Zn}$ in the budding stage, and the percentage of the F4 fraction of $\mathrm{Cd}$ in the filling, and maturity stages. Accordingly, the percentage of the F1 and F2 fractions of $\mathrm{Zn}$ and $\mathrm{Cd}$ for the $\mathrm{C} 1$ treatment showed a decreasing trend compared with CK. These results indicate that low amounts of SSB amendments can promote immobilization of PTEs in the soil during different stages and reduce the risk off uptake by corn plants, which can be attributed to the modified microbial activity and the interaction between biochar and inorganic contaminants via ion exchange, anionic attraction, cationic attraction, and precipitation (Zhu et al. 2017). Additionally, the development of the pore structure of soil after the addition of SSB will increase the number of exchange sites and decrease the mobility of PTEs (Khan et al. 2013). These positive effects on the immobilization of PTEs have also been verified in other studies (Shaheen and Rinklebe 2015; Shaheen et al. 2015). However, an increase in SSB amendment had a negative influence on the stability of the chemical speciation of $\mathrm{Ni}, \mathrm{Cu}$, and $\mathrm{Cd}$. Furthermore, the chemical speciation of $\mathrm{Cr}$ and $\mathrm{Pb}$ showed no significant variation after the addition of SSB. Our previous study verified that $\mathrm{Cr}$ and $\mathrm{Pb}$ mainly existed in SSB as stable fractions combined with silicate minerals, similar to soil (Li et al. 2021).

Unlike other treatments with fertilizer, the percentage of the $\mathrm{F} 4$ fraction of $\mathrm{Cd}$ in the soil for the $\mathrm{C} 2$ treatment (without fertilizer) showed an increasing trend with growth. This indicates that the plant uptake of $\mathrm{Cd}$ will not have significant changes, although the concentration of $\mathrm{Cd}$ in the soil increased in the absence of fertilizer. This inhibition of $\mathrm{Cd}$ stability is attributed to the release of $\mathrm{NH}_{4}{ }^{+}$from fertilizer, which can displace $\mathrm{Cd}$ from adsorption sites (Han et al. 2018). Ammar et al. (2016) also observed that the application of commercial NPK fertilizer enhances the mobility of $\mathrm{Cd}$ in soil. Furthermore, compared with the $\mathrm{C} 2$ treatment, the addition of fertilizer in the $\mathrm{C} 1$ treatment increased the percentage of the $\mathrm{F} 4$ fraction of $\mathrm{Cu}$ at the jointing stage and the percentage of the $\mathrm{F} 4$ fraction of $\mathrm{Zn}$ at the budding stage, suggesting a lower risk of uptake of PTEs by plants. This immobilization effect can be attributed to the importance of phosphorus fertilizers for the immobilization of PTEs via the adsorption or complexation of the phosphate surface on PTE ions and the formation of metal-phosphate precipitates (Xu et al. 2018; Zeeshan et al. 2020).

\subsection{Relation of PTE speciation with soil properties}

The Pearson correlation coefficient shows the degree of correlation between different factors and is widely applied in soil research. Liu et al. (2020) analyzed the correlation of soil characteristics with soybean growth and yield parameters and found that $\mathrm{pH}$ and available nitrogen had a greater impact on the growth of soybean under alkaline soil conditions. Wu et al. (2020b) used this method to analyze soil properties, mineral nutrients, and fruit quality. In the present study, the Pearson coefficient was used to determine the relationships between the F4 fraction of the PTEs in soil and soil physiochemical properties (Fig. 6). The size and color of the squares indicate the strength of correlation, which can be shown by skew-symmetric numbers. The cross suggests a non-significant correlation among the different factors $(P>0.05)$. Chemical speciation of PTEs was markedly influenced by soil $\mathrm{pH}, \mathrm{EC}$, and the concentrations of available phosphorus and potassium. There were significant negative correlations between $\mathrm{pH}$ and the $\mathrm{F} 4$ fractions of $\mathrm{Mn}, \mathrm{Ni}, \mathrm{Cu}, \mathrm{Zn}$, and $\mathrm{As}$, suggesting that the increase in soil $\mathrm{pH}$ inhibited the immobilization of these PTEs. This is because these compounds are stable over a range of $\mathrm{pH}$ values and higher $\mathrm{pH}$ will decrease their solubility in alkaline soils (Wuana and Okieimen 2011). Compared with $\mathrm{pH}$, the correlation demonstrated the opposite trend between EC and the F4 fractions of $\mathrm{Mn}, \mathrm{Ni}, \mathrm{Cu}, \mathrm{Zn}$, and As. Additionally, strong positive correlations were detected between the $\mathrm{F} 4$ fractions of $\mathrm{Cr}$ and $\mathrm{Zn}$ and the concentrations of available 

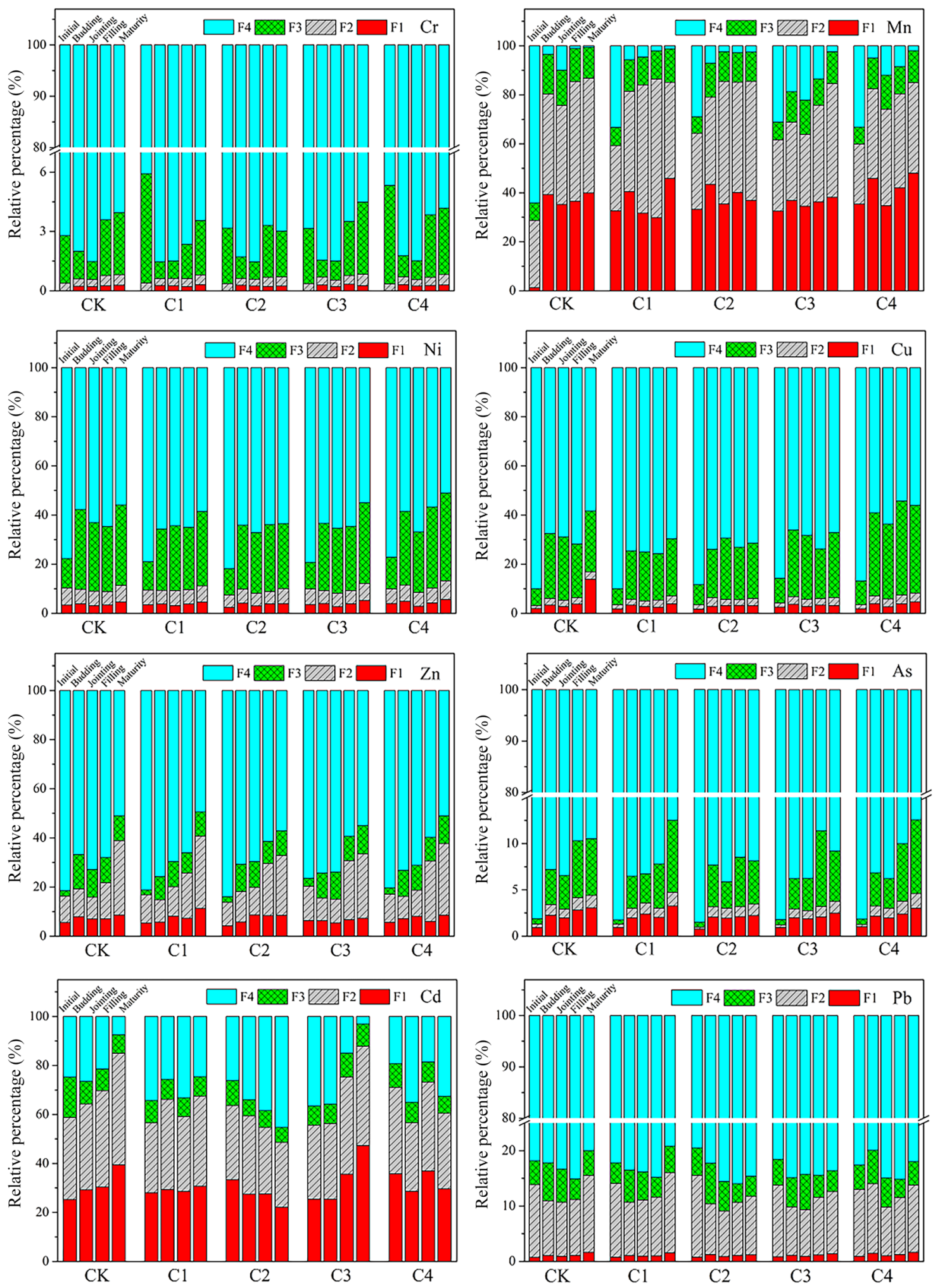

Fig. 5 Variation in the chemical speciation of potentially toxic elements in the soil during growth 


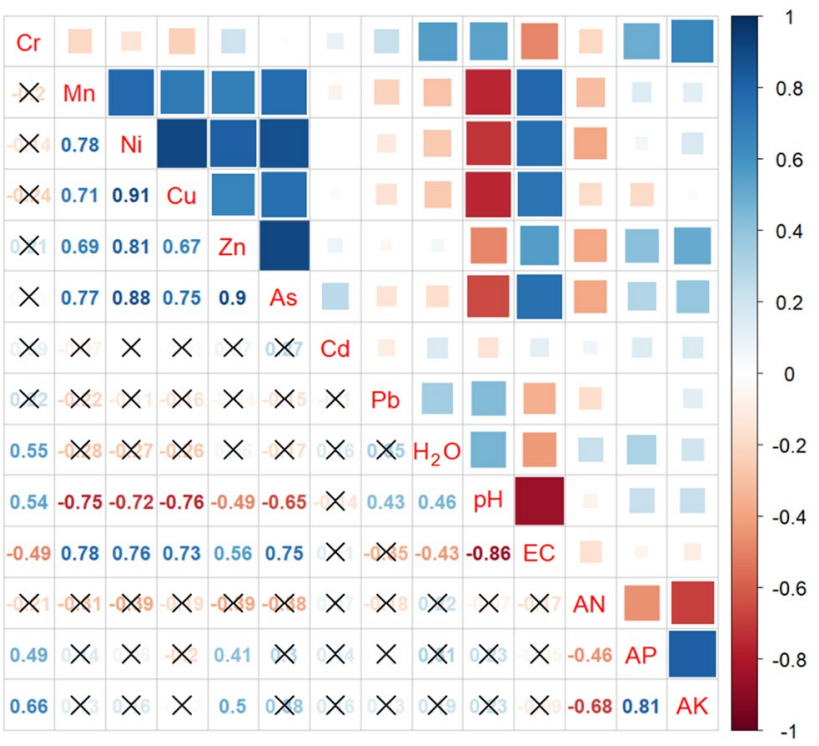

Fig. 6 Pearson correlation between the F4 fractions of potentially toxic elements and soil properties. $\mathrm{H}_{2} \mathrm{O}$ soil moisture, $\mathrm{AN}$ ammonium nitrogen, $A P$ available phosphorus, $A K$ available potassium

phosphorus and potassium. This could be attributed to the fact that an increase in inorganic matter induces precipitation of PTEs, which enhances the transformation of chemical speciation from bioavailable fractions to a more stable fraction (Yue et al. 2017).

\subsection{Corn uptake of PTE and health risk assessment}

The PTE concentrations in the corn fruits (niblets and corncobs) under different treatments are listed in Table 3. Corn fruits had higher levels of $\mathrm{Zn}$ than those of other PTEs because $\mathrm{Zn}$, as an important element, plays a role in enzymatic and redox reactions (Singh et al. 2019). This can be verified in other plants, such as cucumber, rice, and tomato (Hossain et al. 2010; Waqas et al. 2014; Zhang et al. 2016). Concentrations of $\mathrm{Cr}, \mathrm{Mn}, \mathrm{Ni}, \mathrm{Cu}$, and $\mathrm{Zn}$ were lower in the niblets than those in the corncobs, indicating a low consumption risk of PTEs. Additionally, SSB added at $1500 \mathrm{~kg} / \mathrm{hm}^{2}$ significantly decreased the concentrations of $\mathrm{Cr}, \mathrm{Mn}, \mathrm{Ni}, \mathrm{Cu}, \mathrm{Zn}$, and $\mathrm{Pb}$ in the niblets and corncobs. Specifically, the concentrations of $\mathrm{Mn}, \mathrm{Ni}, \mathrm{Cu}$, and $\mathrm{Zn}$ in the niblets decreased by $19.3 \%, 25.3 \%, 42.5 \%$, and $13.6 \%$, respectively, which was closely related to the immobilization of PTEs in the soil. However, a greater amount of SSB increased the $\mathrm{Cu}$ and $\mathrm{Zn}$ concentrations in the corncobs. Al-Wabel et al. (2015) also verified that applying 1.0-5.0 wt\% of Conocarpus biochar significantly reduced $\mathrm{Mn}, \mathrm{Zn}, \mathrm{Cu}$, and $\mathrm{Cd}$ concentrations in corn shoots. The reduction in corn shoots of $\mathrm{Cr}$ and $\mathrm{Cu}$ was observed after the addition of $5 \mathrm{wt} \%$ biochar obtained from jujube leaves and manure (Rafique et al. 2020). Furthermore, the $\mathrm{As}$ and $\mathrm{Pb}$ concentrations in the niblets and the $\mathrm{Cr}, \mathrm{Mn}, \mathrm{Ni}$, $\mathrm{Cu}$, and $\mathrm{Zn}$ concentrations in the corncobs for the $\mathrm{C} 1$ treatment were significantly decreased compared with those in the absence of the fertilizer $(\mathrm{C} 2)$ treatment, indicating that the absence of fertilizer increases the consumption risk of corn plants.

EDI and HQ are associated with the health risk of PTEs via niblet intake, as listed in Table 4. The estimated EDI values of PTEs (except As) for the control were lower than the tolerable limit ( or $\mathrm{R}_{\mathrm{f}} \mathrm{D}$ ), indicating that the intake of PTEs in humans was without substantial risk over a whole lifetime. Furthermore, the addition of moderate SSB decreased the EDI values of $\mathrm{Cr}, \mathrm{Mn}, \mathrm{Ni}, \mathrm{Cu}, \mathrm{Zn}$, and $\mathrm{Pb}$, which was influenced by the PTE concentrations in the niblets. If the HQ of food plants is lower than 1, there is no health risk associated with their consumption. It was found that the HQ values of PTEs (except As) were far lower than the regulated threshold and all HQ values were lower than those obtained in contaminated soils (Khan et al. 2020, 2014). Additionally, lower HQ values were obtained in the treatments combining SSB and fertilizer, suggesting a reduction in the health risk of niblets.
Table 3 Potentially toxic element concentrations in the corn fruits from different treatments

\begin{tabular}{llllllllll}
\hline Sample & Treatment & $\mathrm{Cr}$ & $\mathrm{Mn}$ & $\mathrm{Ni}$ & $\mathrm{Cu}$ & $\mathrm{Zn}$ & $\mathrm{As}$ & $\mathrm{Cd}$ & $\mathrm{Pb}$ \\
\hline Niblet & $\mathrm{CK}$ & $0.92 \mathrm{a}^{\mathrm{a}}$ & $5.54 \mathrm{a}$ & $0.83 \mathrm{a}$ & $2.26 \mathrm{a}$ & $27.15 \mathrm{a}$ & $0.08 \mathrm{~b}$ & $0.02 \mathrm{a}$ & $0.20 \mathrm{~b}$ \\
& $\mathrm{C} 1$ & $0.86 \mathrm{a}$ & $4.47 \mathrm{~b}$ & $0.62 \mathrm{~b}$ & $1.30 \mathrm{~b}$ & $23.45 \mathrm{~b}$ & $0.08 \mathrm{~b}$ & $0.02 \mathrm{a}$ & $0.18 \mathrm{bc}$ \\
& $\mathrm{C} 2$ & $0.78 \mathrm{a}$ & $4.66 \mathrm{~b}$ & $0.60 \mathrm{~b}$ & $1.25 \mathrm{~b}$ & $23.35 \mathrm{~b}$ & $0.10 \mathrm{a}$ & $0.02 \mathrm{a}$ & $0.41 \mathrm{a}$ \\
& $\mathrm{C} 3$ & $0.21 \mathrm{c}$ & $3.61 \mathrm{c}$ & $0.31 \mathrm{c}$ & $1.30 \mathrm{~b}$ & $18.99 \mathrm{c}$ & $0.08 \mathrm{~b}$ & $0.02 \mathrm{a}$ & $0.16 \mathrm{bc}$ \\
& $\mathrm{C} 4$ & $0.59 \mathrm{~b}$ & $4.00 \mathrm{bc}$ & $0.33 \mathrm{c}$ & $1.32 \mathrm{~b}$ & $16.89 \mathrm{c}$ & $0.03 \mathrm{c}$ & $0.02 \mathrm{a}$ & $0.14 \mathrm{~d}$ \\
Corncob & $\mathrm{CK}$ & $9.32 \mathrm{a}$ & $8.98 \mathrm{a}$ & $4.43 \mathrm{a}$ & $2.71 \mathrm{~b}$ & $35.70 \mathrm{a}$ & $0.06 \mathrm{c}$ & $0.02 \mathrm{a}$ & $0.18 \mathrm{a}$ \\
& $\mathrm{C} 1$ & $4.00 \mathrm{c}$ & $5.20 \mathrm{~d}$ & $1.70 \mathrm{~d}$ & $1.96 \mathrm{c}$ & $18.59 \mathrm{c}$ & $0.06 \mathrm{c}$ & $0.02 \mathrm{a}$ & $0.11 \mathrm{c}$ \\
& $\mathrm{C} 2$ & $5.71 \mathrm{~b}$ & $6.81 \mathrm{~b}$ & $2.33 \mathrm{c}$ & $3.19 \mathrm{a}$ & $27.38 \mathrm{~b}$ & $0.06 \mathrm{c}$ & $0.02 \mathrm{a}$ & $0.11 \mathrm{c}$ \\
& $\mathrm{C} 3$ & $6.95 \mathrm{~b}$ & $8.56 \mathrm{a}$ & $3.49 \mathrm{~b}$ & $3.05 \mathrm{a}$ & $32.72 \mathrm{a}$ & $0.08 \mathrm{~b}$ & $0.03 \mathrm{a}$ & $0.12 \mathrm{bc}$ \\
& $\mathrm{C} 4$ & $3.63 \mathrm{c}$ & $6.46 \mathrm{bc}$ & $1.17 \mathrm{e}$ & $2.67 \mathrm{~b}$ & $35.71 \mathrm{a}$ & $0.13 \mathrm{a}$ & $0.02 \mathrm{a}$ & $0.14 \mathrm{~b}$ \\
\hline
\end{tabular}

${ }^{a}$ Letters after the numerical value show significance differences with each column of data $(P<0.05)$ 
Table 4 Estimated daily intake $(\mu \mathrm{g} / \mathrm{kg} / \mathrm{day})$ and hazard quotient for potentially toxic elements associated with the consumption of corn

\begin{tabular}{|c|c|c|c|c|c|c|c|c|c|c|}
\hline & \multicolumn{5}{|l|}{ EDI } & \multicolumn{5}{|l|}{ HQ } \\
\hline & $\overline{\mathrm{CK}}$ & $\mathrm{C} 1$ & $\mathrm{C} 2$ & $\mathrm{C} 3$ & $\mathrm{C} 4$ & $\overline{\mathrm{CK}}$ & $\mathrm{C} 1$ & $\mathrm{C} 2$ & C3 & $\mathrm{C} 4$ \\
\hline $\mathrm{Cr}$ & 6.45 & 6.03 & 5.47 & 1.47 & 4.14 & 0.00 & 0.00 & 0.00 & 0.00 & 0.00 \\
\hline $\mathrm{Mn}$ & 38.84 & 31.34 & 32.67 & 25.31 & 28.04 & 0.28 & 0.22 & 0.23 & 0.18 & 0.20 \\
\hline $\mathrm{Ni}$ & 5.82 & 4.35 & 4.21 & 2.17 & 2.31 & 0.29 & 0.22 & 0.21 & 0.11 & 0.12 \\
\hline $\mathrm{Cu}$ & 15.84 & 9.11 & 8.76 & 9.11 & 9.25 & 0.40 & 0.23 & 0.22 & 0.23 & 0.23 \\
\hline $\mathrm{Zn}$ & 190.34 & 164.40 & 163.70 & 133.13 & 118.41 & 0.63 & 0.55 & 0.55 & 0.44 & 0.39 \\
\hline As & 0.56 & 0.56 & 0.70 & 0.63 & 0.21 & 1.87 & 1.87 & 2.34 & 1.87 & 0.70 \\
\hline $\mathrm{Cd}$ & 0.14 & 0.14 & 0.14 & 0.14 & 0.14 & 0.05 & 0.05 & 0.05 & 0.05 & 0.05 \\
\hline $\mathrm{Pb}$ & 1.40 & 1.26 & 2.87 & 1.12 & 0.98 & 0.40 & 0.36 & 0.82 & 0.32 & 0.28 \\
\hline
\end{tabular}

\section{Conclusions}

With the amendment of $1500 \mathrm{~kg} / \mathrm{hm}^{2}$ sewage sludge biochar applied to the alkaline soil, the fruit yield of corn plants was increased. However, higher biochar applications $\left(4500-9000 \mathrm{~kg} / \mathrm{hm}^{2}\right)$ inhibited the growth of corn plants due to the high nutrient levels. Moderate sewage sludge biochar amendments had no significant effect on total potentially toxic element concentrations and promoted the immobilization of $\mathrm{Ni}, \mathrm{Cu}, \mathrm{Zn}$, and $\mathrm{Cd}$ in the alkaline soil, which was markedly influenced by soil $\mathrm{pH}$, electrical conductivity, and available phosphorus and potassium concentrations. In particular, the concentrations of $\mathrm{Mn}, \mathrm{Ni}, \mathrm{Cu}$, and $\mathrm{Zn}$ in niblets decreased significantly after the addition of $1500 \mathrm{~kg} / \mathrm{hm}^{2}$ biochar, and the health risk associated with fruit consumption was reduced. Furthermore, the combination of biochar and fertilizer improved the effect on corn growth and reduced the risk of potentially toxic elements. Collectively, this work shows that $1500 \mathrm{~kg} / \mathrm{hm}^{2}$ of sewage sludge biochar applied to alkaline soils is a realistically achievable rate considering the increase in corn fruit yield and the decrease in consumption risk.

Acknowledgements This work was supported by the National Key Research and Development Project [2020YFC1908904], Science and Technology Program of Xiamen [3502Z20193076], Natural Science Foundation of Fujian Province [2019J01135], Strategic Priority Research Program of the Chinese Academy of Sciences [XDA23020504].

Author contributions SX: conceptualization, investigation, formal analysis, visualization, writing-original draft. GY: conceptualization, writing-review and editing, project administration, supervision. RJ: investigation. JM: writing-review and editing. XS: investigation. GW: investigation. YW: project administration, supervision. YY: investigation. CL: writing-review and editing.

Open Access This article is licensed under a Creative Commons Attribution 4.0 International License, which permits use, sharing, adaptation, distribution and reproduction in any medium or format, as long as you give appropriate credit to the original author(s) and the source, provide a link to the Creative Commons licence, and indicate if changes were made. The images or other third party material in this article are included in the article's Creative Commons licence, unless indicated otherwise in a credit line to the material. If material is not included in the article's Creative Commons licence and your intended use is not permitted by statutory regulation or exceeds the permitted use, you will need to obtain permission directly from the copyright holder. To view a copy of this licence, visit http://creativecommons.org/licenses/by/4.0/.

\section{References}

Al-Wabel MI, Usman ARA, El-Naggar AH, Aly AA, Ibrahim HM, Elmaghraby S, Al-Omran A (2015) Conocarpus biochar as a soil amendment for reducing heavy metal availability and uptake by maize plants. Saudi J Biol Sci 22:503-511. https:// doi.org/10.1016/j.sjbs.2014.12.003

Ammar R, Kanbar HJ, Kazpard V, Wazne M, El Samrani AG, Amacha N, Saad Z, Chou L (2016) Role of phosphogypsum and NPK amendments on the retention or leaching of metals in different soils. J Environ Manag 178:20-29. https://doi.org/10.1016/j. jenvman.2016.04.042

Artiola JF, Rasmussen C, Freitas R (2012) Effects of a biocharamended alkaline soil on the growth of romaine lettuce and bermudagrass. Soil Sci 177:561-570. https://doi.org/10.1097/ SS.0b013e31826ba908

Atafar Z, Mesdaghinia A, Nouri J, Homaee M, Yunesian M, Ahmadimoghaddam M, Mahvi AH (2008) Effect of fertilizer application on soil heavy metal concentration. Environ Monit Assess 160:83. https://doi.org/10.1007/s10661-008-0659-x

Ding Y, Liu Y, Liu S, Li Z, Tan X, Huang X, Zeng G, Zhou L, Zheng B (2016) Biochar to improve soil fertility. A review. Agron Sustain Dev 36:36. https://doi.org/10.1007/s13593-016-0372-z

El-Fouly M, Abou El-Nour E, Shaaban S, Zeidan M (2012) Effect of different levels of NPK and micronutrients fertilization on yield and nutrient uptake of maize plants. J Am Sci 8:209-214

Figueiredo C, Lopes H, Coser T, Vale A, Busato J, Aguiar N, Novotny E, Canellas L (2018) Influence of pyrolysis temperature on chemical and physical properties of biochar from sewage sludge. Arch Agron Soil Sci 64:881-889. https://doi.org/10.1080/03650 340.2017.1407870

Fuentes A, Lloréns M, Sáez J, Isabel Aguilar MA, Ortuño JF, Meseguer VF (2008) Comparative study of six different sludges by sequential speciation of heavy metals. Bioresour Technol 99:517-525. https://doi.org/10.1016/j.biortech.2007.01.025

Haider G, Steffens D, Moser G, Müller C, Kammann CI (2017) Biochar reduced nitrate leaching and improved soil moisture content without yield improvements in a four-year field study. Agric Ecosyst Environ 237:80-94. https://doi.org/10.1016/j. agee.2016.12.019 
Han X-q, Xiao X-y, Guo Z-h, Xie Y-h, Zhu H-w, Peng C, Liang Y-q (2018) Release of cadmium in contaminated paddy soil amended with NPK fertilizer and lime under water management. Ecotoxicol Environ Saf 159:38-45. https://doi.org/10.1016/j. ecoenv.2018.04.049

Hossain MK, Strezov V, Yin Chan K, Nelson PF (2010) Agronomic properties of wastewater sludge biochar and bioavailability of metals in production of cherry tomato (Lycopersiconesculentum). Chemosphere 78:1167-1171. https://doi.org/10.1016/j. chemosphere.2010.01.009

Hossain MK, Strezov V, Chan KY, Ziolkowski A, Nelson PF (2011) Influence of pyrolysis temperature on production and nutrient properties of wastewater sludge biochar. J Environ Manag 92:223-228. https://doi.org/10.1016/j.jenvman.2010.09.008

Khan S, Chao C, Waqas M, Arp HPH, Zhu YG (2013) Sewage sludge biochar influence upon rice (Oryza sativa $\mathrm{L}$ ) yield, metal bioaccumulation and greenhouse gas emissions from acidic paddy soil. Environ Sci Technol 47:8624-8632. https://doi.org/10.1021/ es400554x

Khan S, Reid BJ, Li G, Zhu Y-G (2014) Application of biochar to soil reduces cancer risk via rice consumption: a case study in Miaoqian village, Longyan, China. Environ Int 68:154-161. https://doi. org/10.1016/j.envint.2014.03.017

Khan AZ, Ding X, Khan S, Ayaz T, Fidel R, Khan MA (2020) Biochar efficacy for reducing heavy metals uptake by Cilantro (Coriandrum sativum) and spinach (Spinaccia oleracea) to minimize human health risk. Chemosphere 244:125543. https://doi. org/10.1016/j.chemosphere.2019.125543

Kocsis T, Kotroczó Z, Kardos L, Biró B (2020) Optimization of increasing biochar doses with soil-plant-microbial functioning and nutrient uptake of maize. Environ Technol Innov 20:101191. https://doi.org/10.1016/j.eti.2020.101191

Li XG, Jia B, Lv J, Ma Q, Kuzyakov Y, Li F-m (2017) Nitrogen fertilization decreases the decomposition of soil organic matter and plant residues in planted soils. Soil Biol Biochem 112:47-55. https://doi.org/10.1016/j.soilbio.2017.04.018

Li C, Wang X, Zhang G, Li J, Li Z, Yu G, Wang Y (2018a) A process combining hydrothermal pretreatment, anaerobic digestion and pyrolysis for sewage sludge dewatering and co-production of biogas and biochar: pilot-scale verification. Bioresour Technol 254:187-193. https://doi.org/10.1016/j.biortech.2018.01.045

Li Y, He N, Hou J, Li X, Liu C, Zhang J, Wang Q, Zhang X, Wu $X(2018 b)$ Factors influencing leaf chlorophyll content in natural forests at the biome scale. Front Ecol Evol 6:64. https://doi. org/10.3389/fevo.2018.00064

Li Q, Wang M, Fu Q, Li T, Liu D, Hou R, Li H, Cui S, Ji Y (2020) Short-term influence of biochar on soil temperature, liquid moisture content and soybean growth in a seasonal frozen soil area. J Environ Manag 266:110609. https://doi.org/10.1016/j.jenvm an.2020.110609

Li C, Xie S, You F, Zhu X, Li J, Xu X, Yu G, Wang Y, Angelidaki I (2021) Heavy metal stabilization and improved biochar generation via pyrolysis of hydrothermally treated sewage sludge with antibiotic mycelial residue. Waste Manag 119:152-161. https:// doi.org/10.1016/j.wasman.2020.09.050

Liu D, Feng Z, Zhu H, Yu L, Yang K, Yu S, Zhang Y, Guo W (2020) Effects of corn straw biochar application on soybean growth and alkaline soil properties. BioResources 15:1463-1481. https://doi. org/10.15376/biores.15.1.1463-1481

Mandal S, Thangarajan R, Bolan NS, Sarkar B, Khan N, Ok YS, Naidu $\mathrm{R}$ (2016) Biochar-induced concomitant decrease in ammonia volatilization and increase in nitrogen use efficiency by wheat. Chemosphere 142:120-127. https://doi.org/10.1016/j.chemospher e.2015.04.086

Mohamed BA, Ellis N, Kim CS, Bi X (2017) The role of tailored biochar in increasing plant growth, and reducing bioavailability, phytotoxicity, and uptake of heavy metals in contaminated soil. Environ Pollut 230:329-338. https://doi.org/10.1016/j.envpo 1.2017.06.075

Negasa T, Ketema H, Legesse A, Sisay M, Temesgen H (2017) Variation in soil properties under different land use types managed by smallholder farmers along the toposequence in southern Ethiopia. Geoderma 290:40-50. https://doi.org/10.1016/j.geode rma.2016.11.021

Neina D (2019) The role of soil pH in plant nutrition and soil remediation. Appl Environ Soil Sci 2019:5794869. https://doi. org/10.1155/2019/5794869

Oni BA, Oziegbe O, Olawole OO (2019) Significance of biochar application to the environment and economy. Ann Agric Sci 64:222236. https://doi.org/10.1016/j.aoas.2019.12.006

Pokharel P, Ma Z, Chang SX (2020) Biochar increases soil microbial biomass with changes in extra- and intracellular enzyme activities: a global meta-analysis. Biochar 2:65-79. https://doi. org/10.1007/s42773-020-00039-1

Purakayastha TJ, Bera T, Bhaduri D, Sarkar B, Mandal S, Wade P, Kumari S, Biswas S, Menon M, Pathak H, Tsang DCW (2019) A review on biochar modulated soil condition improvements and nutrient dynamics concerning crop yields: pathways to climate change mitigation and global food security. Chemosphere 227:345-365. https://doi.org/10.1016/j.chemospher e.2019.03.170

Rafael RB, FERNÁNDEZ-MARCOS ML, Cocco S, Ruello ML, Fornasier F, Corti G (2019) Benefits of biochars and NPK fertilizers for soil quality and growth of cowpea (Vigna unguiculata L. Walp.) in an acid Arenosol. Pedosphere 29:311-333. https://doi. org/10.1016/S1002-0160(19)60805-2

Rafique MI, Usman ARA, Ahmad M, Sallam A, Al-Wabel MI (2020) In situ immobilization of $\mathrm{Cr}$ and its availability to maize plants in tannery waste-contaminated soil: effects of biochar feedstock and pyrolysis temperature. J Soils Sediments 20:330-339. https://doi. org/10.1007/s11368-019-02399-z

Scianna J (2002) Salt-affected soils: their causes, measure, and classification. Plant Materials Program Hort. Note No. 5:1-3

Shaheen SM, Rinklebe J (2015) Impact of emerging and low cost alternative amendments on the (im) mobilization and phytoavailability of $\mathrm{Cd}$ and $\mathrm{Pb}$ in a contaminated floodplain soil. Ecol Eng 74:319-326. https://doi.org/10.1016/j.ecoleng.2014.10.024

Shaheen SM, Rinklebe J, Selim MH (2015) Impact of various amendments on immobilization and phytoavailability of nickel and zinc in a contaminated floodplain soil. Int J Environ Sci Technol 12:2765-2776. https://doi.org/10.1007/s13762-014-0713-x

Shehata HS, Galal TM (2020) Trace metal concentration in planted cucumber (Cucumis sativus L.) from contaminated soils and its associated health risks. J Consum Prot Food Saf. https://doi. org/10.1007/s00003-020-01284-Z

Singh R, Jha AB, Misra AN, Sharma P (2019) Chapter 13 - adaption mechanisms in plants under heavy metal stress conditions during phytoremediation. In: Pandey VC, Bauddh K (eds) Phytomanagement of polluted sites. Elsevier, Amsterdam, pp 329-360. https:// doi.org/10.1016/B978-0-12-813912-7.00013-2

Sun H, Dan A, Feng Y, Vithanage M, Mandal S, Shaheen SM, Rinklebe J, Shi W, Wang H (2019) Floating duckweed mitigated ammonia volatilization and increased grain yield and nitrogen use efficiency of rice in biochar amended paddy soils. Chemosphere 237:124532. https://doi.org/10.1016/j.chemosphere.2019.124532

Tian R, Li C, Xie S, You F, Cao Z, Xu Z, Yu G, Wang Y (2019) Preparation of biochar via pyrolysis at laboratory and pilot scales to remove antibiotics and immobilize heavy metals in livestock feces. J Soils Sediments 19:2891-2902. https://doi.org/10.1007/ s11368-019-02350-2

Waqas M, Khan S, Qing H, Reid BJ, Chao C (2014) The effects of sewage sludge and sewage sludge biochar on PAHs and potentially 
toxic element bioaccumulation in Cucumis sativa $\mathrm{L}$. Chemosphere 105:53-61. https://doi.org/10.1016/j.chemosphere.2013.11.064

Wu P, Ata-Ul-Karim ST, Singh BP, Wang H, Wu T, Liu C, Fang G, Zhou D, Wang Y, Chen W (2019) A scientometric review of biochar research in the past 20 years (1998-2018). Biochar 1:23-43. https://doi.org/10.1007/s42773-019-00002-9

Wu P, Wang Z, Wang H, Bolan NS, Wang Y, Chen W (2020a) Visualizing the emerging trends of biochar research and applications in 2019: a scientometric analysis and review. Biochar 2:135-150. https://doi.org/10.1007/s42773-020-00055-1

Wu S, Zhang Y, Tan Q, Sun X, Wei W, Hu C (2020b) Biochar is superior to lime in improving acidic soil properties and fruit quality of Satsuma mandarin. Sci Total Environ 714:136722. https://doi. org/10.1016/j.scitotenv.2020.136722

Wuana RA, Okieimen FE (2011) Heavy metals in contaminated soils: a review of sources, chemistry, risks and best available strategies for remediation. ISRN Ecol 2011:402647. https://doi. org/10.5402/2011/402647

Xie S, Yu G, Li C, You F, Li J, Tian R, Wang G, Wang Y (2019) Dewaterability enhancement and heavy metals immobilization by pig manure biochar addition during hydrothermal treatment of sewage sludge. Environ Sci Pollut Res 26:16537-16547. https:// doi.org/10.1007/s11356-019-04961-1

Xie S, Yu G, Li C, Li J, Wang G, Dai S, Wang Y (2020a) Treatment of high-ash industrial sludge for producing improved char with low heavy metal toxicity. J Anal Appl Pyrolysis 150:104866. https:// doi.org/10.1016/j.jaap.2020.104866

Xie S, Yu G, Ma J, Wang G, Wang Q, You F, Li J, Wang Y, Li C (2020b) Chemical speciation and distribution of potentially toxic elements in soilless cultivation of cucumber with sewage sludge biochar addition. Environ Res 191:110188. https://doi. org/10.1016/j.envres.2020.110188

Xu M, Zhou S, Chen S (2018) Remediation of heavy metal-contaminated soils by phosphate fertilizers. In: Luo Y, Tu C (eds) Twenty years of research and development on soil pollution and remediation in China. Springer Singapore, Singapore, pp 545-562. https ://doi.org/10.1007/978-981-10-6029-8_33

Yu G, Xie S, Ma J, Shang X, Wang Y, Yu C, You F, Tang X, Levatti HU, Pan L, Li J, Li C (2018) Influence of sewage sludge biochar on the microbial environment, chinese cabbage growth, and heavy metals availability of soil. In: Biochar-an imperative amendment for soil and the environment. IntechOpen. https://doi.org/10.5772/ intechopen.82091

Yue Y, Cui L, Lin Q, Li G, Zhao X (2017) Efficiency of sewage sludge biochar in improving urban soil properties and promoting grass growth. Chemosphere 173:551-556. https://doi.org/10.1016/j. chemosphere.2017.01.096

Zeeshan M, Ahmad W, Hussain F, Ahamd W, Numan M, Shah M, Ahmad I (2020) Phytostabalization of the heavy metals in the soil with biochar applications, the impact on chlorophyll, carotene, soil fertility and tomato crop yield. J Clean Prod 255:120318. https:// doi.org/10.1016/j.jclepro.2020.120318

Zhang H, Huang Y, Liu G, Xu Y, Liu J, Bei Q, Lin X, Zhu J, Xie Z (2010) Effects of biochar on corn growth, nutrient uptake and soil chemical properties in seeding stage. Ecol Environ Sci 19:27132717 (in Chinese)

Zhang Y, Chen T, Liao Y, Reid BJ, Chi H, Hou Y, Cai C (2016) Modest amendment of sewage sludge biochar to reduce the accumulation of cadmium into rice (Oryza sativa L.): a field study. Environ Pollut 216:819-825. https://doi.org/10.1016/j.envpol.2016.06.053

Zheng N, Wang Q, Zhang X, Zheng D, Zhang Z, Zhang S (2007) Population health risk due to dietary intake of heavy metals in the industrial area of Huludao city, China. Sci Total Environ 387:96104. https://doi.org/10.1016/j.scitotenv.2007.07.044

Zhu XM, Chen BL, Zhu LZ, Xing BS (2017) Effects and mechanisms of biochar-microbe interactions in soil improvement and pollution remediation: a review. Environ Pollut 227:98-115. https:// doi.org/10.1016/j.envpol.2017.04.032 